JEL: Q10, Q13, C10

\title{
Paul-Alfred Kouakou KOUAKOU
}

\author{
Peleforo Gon Coulibaly University \\ Republic of Ivory Coast
}

\section{ROLE OF TRADE IN NATURAL RUBBER AND PALM OIL IN THE COMPOSITION OF GDP IN IVORY COAST}

Purpose. This paper discusses the effect of natural rubber and palm oil exports on economic growth in Ivory Coast from 1980 to 2016 using World Bank data.

Methodology / approach. The analysis involved the use of Augmented Dickey-Fuller (ADF) and Phillips-Perron (PP) unit root tests and the ARDL model.

Results. This paper discusses the effect of natural rubber and palm oil exports on economic growth in Ivory Coast from 1980 to 2016 using World Bank data. The analysis involved the use of Augmented Dickey-Fuller (ADF) and Phillips-Perron (PP) unit root tests and the ARDL model. The results of the study show that there is a positive and non-significant relationship between natural rubber exports and short-term economic growth. On the other hand, in the long term, they have a positive and significant influence on economic development. However, in the short and long term, palm oil exports have a positive and significant impact on gross domestic product. Finally, labour, investment and market opening have a positive and significant effect on economic growth in the short and long term respectively. Therefore, the Ivorian government needs to promote good agricultural practices and agricultural financing in order to increase the competitiveness of the Hevea-Oil palm sector.

Originality / scientific novelty. Previous studies in natural rubber and palm oil focused mainly on its production, constraints to production and processing. However, very few studies on its effects on economic growth have been done so far. This study fills that gap. It expanded the existing literature and the subject of the causal relationship between natural rubber and palm oil exports and economic growth in Ivory Coast and shed light on required efforts to enhance the production and utilization of natural rubber and palm oil at larger scale to bring economic development in Ivory Coast. At last, the ARDL model is used to address this issue.

Practical value / implications. The generated information will be useful to a number of organizations including: research and development, marketers, producers, policy makers, government and non-governmental organizations to assess their activities and improve their mode of operations, to help better guide the design and implementation of policies and strategies. Finally, knowing the existing relationship between natural rubber and palm oil exports and economic growth, together with impediments faced by natural rubber and palm oil exports, the study provides the various ways to improve these exports by increasing exports capacity of local producers. Research on this issue is too important to inform policymakers regarding resource allocation in the natural rubber and palm oil sector to achieve economic growth.

Key words: exports, economic growth, natural rubber, palm oil, Ivory Coast.

Introduction and review of literature. At the dawn of independence, African countries were less endowed in human capital and technology than those in the North. Thus, the fertility of their soils combined with good climatic conditions led them to turn naturally to the agricultural sector, which they saw as an engine of 
economic development and a comparative advantage. Ivory Coast did not escape this situation by opting for an agrarian-type rentier system.

Agriculture contributes to the creation of more than $22.3 \%$ of GDP and represents more than $47 \%$ of the country's overall exports in 2013 (62\% excluding oil) according to Banque Mondiale [BM] (2016). This sector employs more than $46 \%$ of Ivory Coast's working population and is a source of income for two-thirds of the Ivorian population, 50.3\% of whom are rural (Institut National de la Statistique [INS], 2014).

However, Ivory Coast's dependence on world prices and the State's involvement in the productive economy plunged the country into a deep crisis from 1980 to 1993. This crisis was characterized by a sharp fall in economic growth, a significant drop in per capita income, and the aggravation of internal and external imbalances (deterioration of the balance of payments, growing public deficits).

In order to remedy this situation, the country embarked from 1994 on a process of liberalization of its economy under the aegis of the Bretton Woods institutions. Several structural adjustment programmes were adopted. These programmes consisted in the gradual disengagement of the State from the productive sphere through privatization reform. Furthermore, export diversification remains one of the watchwords of the government's strategy. Several agricultural export products were introduced to create wealth, namely oil palm and natural rubber in the southern and western half of the country (Zamblé, 2015).

Today, Ivory Coast ranks first (1st) in Africa and seventh (7th) in the world in the production of natural rubber. Natural rubber is also the third (3rd) export product in Ivory Coast and the second (2nd) non-oil, representing $6 \%$ of the country's exports. As for palm oil, it is the fourth (4th) in the Ivorian economy and employs more than one million people. With 400,000 tons of crude palm oil produced per year, Ivory Coast ranks fifth (5th) in the world after Malaysia, Indonesia, Nigeria and Colombia. Moreover, it is the first (1st) African exporter and the second (2nd) African producer behind Nigeria (BM, 2016). Ivory Coast has 75,000 ha of industrial oil palm plantations and 155,000 ha of village plantations. The sector generates 220,000 direct jobs, feeds more than two million people and accounts for $1.5 \%$ of GDP. The country holds $90 \%$ of the West African Economic and Monetary Union (WAEMU) market, consumes $60 \%$ of its production and exports $25 \%$. The turnover is 170 billion CFA francs for crude palm oil and 280 billion CFA francs for byproducts such as soap (Maxime, 2020).

Therefore, the objective of this study is to assess the effect of the hevea and oil palm sector to economic growth in Ivory Coast. Specifically, it aims to determine the causal effect of natural rubber and palm oil exports on economic growth in Ivory Coast.

Several empirical studies focused fundamentally on the relationship between exports, trade and economic growth in several countries. For example, Tamaschke's (1979) econometric work on the states of Victoria and New South Wales showed that commodity exports contributed significantly to the GDP of both states. However, 
according to the same author, the driving role was only evident if indirect effects such as linkage effects arising from transport and railways mainly were added.

In the same vein, making estimates on cross-sectional data to overcome the drawbacks of the Balassa methodology with a set of 55 developing countries over the period 1960-1977, Tyler (1981) confirmed the role played by exports in economic growth and argued that countries that neglect the export sector should expect a low rate of economic growth.

In addition, Rodrigue (1987), studying 19 OECD (Organization for Economic Cooperation and Development) countries (Belgium, Canada, Denmark, Finland, France, Germany, Greece, Ireland, Italy, Japan, the Netherlands, New Zealand, Norway, Spain, Sweden, Switzerland, Austria, the United Kingdom, the United States and the United Kingdom) from 1966 to 1983, using cross-sectional tests, stated that growth in OECD countries was stimulated significantly by both export and investment growth rates.

Henneberry and Curry (2010) examined the relationship between agricultural exports and economic growth in Pakistan. Using three simultaneous equations representing GDP, agricultural exports, and imports, they found a favourable relationship between agricultural exports and economic growth in the country.

Along the same lines, Kpémoua (2016) in his study on the impact of exports on economic growth in Togo showed that there was a causal relationship between exports and economic growth by using a model based on a neoclassical production function.

Rakhmetullina et al. (2017) found an empirical relationship between agriculture and economic growth in Nigeria using autoregressive distributed lag model (ARDL) and vector error correction model (VECM).

Khan and Ansari (2018) studied the contribution of agriculture to economic growth in Uttar Pradesh, India. The study employed a long-run cointegrating analysis and found that agricultural development drives economic growth. Based on their findings, they suggested the public investment in irrigation, credit to farmers and the supports for micro and small agro-based industrialists as the strategic actions to achieve economic growth in India.

Faycal and Ali (2016) analyzed the impact of agricultural production on the economic growth in Algeria using the Autoregressive Distributed Lag (ARDL) model. The study revealed that the impact of agriculture on the economic growth was negative in the long-run when the governmental support was focused only on the production side of the agricultural sector. Otherwise, when the support is for the agricultural sector as a whole, the impact turns into positive.

Finally, Zahonogo (2017) used a dynamic growth model and employed the pooled mean group estimation technique and tested the empirical link between trade and economic growth for 42 sub-Saharan African countries. According to the results, the link between trade and economic growth was non-linear for these sub-Saharan African countries. Moreover, there is a threshold below which international trade is beneficial to economic growth. 
From all the above, we note that in most cases, exports are a major determinant of economic growth.

The purpose of the article. This paper discusses the effect of natural rubber and palm oil exports on economic growth in Ivory Coast from 1980 to 2016 using World Bank data. Specifically, it aims to determine the causal effect of natural rubber and palm oil exports on economic growth.

Methodology. The data used in this study are the World Bank Development Indicators (WDI). They cover the quantity of natural rubber exported, the quantity of palm oil exported, trade openness, agricultural investment, labour force and GDP from 1980 to 2016. For processing, we used the software Eviews 10. The causal relationship between the export of natural rubber and palm oil and economic growth are studied using the ARDL model. The dependent variable is GDP. The explanatory variables are: the quantity of rubber produced as a proxy variable for the quantity of natural rubber exported; the quantity of oil palm produced as a proxy variable for the quantity of palm oil exported; trade openness; labour force and agricultural investment.

The ARDL model can be written as follows (Eq. 1):

$$
\mathrm{GDP}=\mathrm{F}(\mathrm{HEV}, \mathrm{PAL}, \mathrm{LAB}, \mathrm{TRA}, \mathrm{INV})
$$

The Long Term Equation can be written as follows (Eq. 2):

$$
\begin{aligned}
& \operatorname{LnGDP}_{\mathrm{t}}=\alpha_{0}+\varphi \sum_{\mathrm{i}=1}^{\mathrm{p}} \operatorname{LnGDP}_{\mathrm{t}-\mathrm{i}}+\alpha_{1} \sum_{\mathrm{i}=0}^{\mathrm{q}} \operatorname{LnHEV}_{\mathrm{t}-\mathrm{i}}+\alpha_{2} \sum_{\mathrm{i}=0}^{\mathrm{q}} \operatorname{LnPAL}_{\mathrm{t}-\mathrm{i}}+ \\
& \alpha_{3} \sum_{\mathrm{i}=0}^{\mathrm{q}} \operatorname{LnINV}_{\mathrm{t}-\mathrm{i}}+\alpha_{4} \sum_{\mathrm{i}=0}^{\mathrm{q}} \operatorname{LnLAB}_{\mathrm{t}-\mathrm{i}}+\alpha_{5} \sum_{\mathrm{i}=0}^{\mathrm{q}} \operatorname{LnTRA}_{\mathrm{t}-\mathrm{i}}+\mu_{\mathrm{t}}
\end{aligned}
$$

The cointegrating relationship equation is obtained from the error correction model (ECM) and is written as follows (Eq. 3):

$$
\begin{aligned}
& \Delta \operatorname{LnGDP}_{\mathrm{t}}=\alpha_{0}+\varphi_{1-\mathrm{j}} \sum_{\mathrm{i}=1}^{\mathrm{p}} \Delta \operatorname{LnGDP}_{\mathrm{t}-\mathrm{i}}+\alpha_{1} \sum_{\mathrm{i}=0}^{\mathrm{q}} \Delta \operatorname{LnHEV}_{\mathrm{t}-\mathrm{i}}+ \\
& \alpha_{2} \sum_{\mathrm{i}=0}^{\mathrm{q}} \Delta \operatorname{LnPAL}_{\mathrm{t}-\mathrm{i}}+\alpha_{3} \sum_{\mathrm{i}=0}^{\mathrm{q}} \Delta \operatorname{LnINV}_{\mathrm{t}-\mathrm{i}}+\alpha_{4} \sum_{\mathrm{i}=0}^{\mathrm{q}} \Delta \operatorname{LnLAB}_{\mathrm{t}-\mathrm{i}}+ \\
& \alpha_{5} \sum_{\mathrm{i}=0}^{\mathrm{q}} \Delta \operatorname{LnTRA}_{\mathrm{t}-\mathrm{i}}+\lambda \mathrm{EC}_{\mathrm{t}-\mathrm{i}}+\mu_{\mathrm{t}}
\end{aligned}
$$

$\lambda \mathrm{EC}_{\mathrm{t}-\mathrm{i}}$, represents the error correction term.

Taking into account the short-term and long-term effects between the explanatory variables and the explained or dependent variable, the ARDL representation is as follows (Eq. 4):

$$
\begin{aligned}
& \Delta \mathrm{GDP}_{\mathrm{t}}=\alpha_{0}+\alpha_{1} \sum_{\mathrm{i}=1}^{\mathrm{p}} \Delta \mathrm{GDP}_{\mathrm{t}-\mathrm{i}}+\alpha_{2} \sum_{\mathrm{i}=0}^{\mathrm{q}} \Delta \mathrm{HEV}_{\mathrm{t}-\mathrm{i}}+\alpha_{3} \sum_{\mathrm{i}=0}^{\mathrm{q}} \Delta \mathrm{PAL}_{\mathrm{t}-\mathrm{i}}+ \\
& \alpha_{4} \sum_{\mathrm{i}=0}^{\mathrm{q}} \Delta \mathrm{INV}_{\mathrm{t}-\mathrm{i}}+\alpha_{5} \sum_{\mathrm{i}=0}^{\mathrm{q}} \Delta \mathrm{LAB}_{\mathrm{t}-\mathrm{i}}+\alpha_{6} \sum_{\mathrm{i}=0}^{\mathrm{q}} \Delta \mathrm{TRA}_{\mathrm{t}-\mathrm{i}}+\lambda_{1} \mathrm{LnGDP}_{\mathrm{t}-1}+ \\
& \lambda_{2} \operatorname{LnHEV}_{\mathrm{t}-1}+\lambda_{3} \mathrm{PAL}_{\mathrm{t}-1}+\lambda_{4} \mathrm{INV}_{\mathrm{t}-\mathrm{i}}++\lambda_{5} \mathrm{LAB}_{\mathrm{t}-\mathrm{i}}+\lambda_{6} \mathrm{OC}_{\mathrm{t}-\mathrm{i}}+\mu_{\mathrm{t}}
\end{aligned}
$$

With $\Delta$ : First Difference Operator;

$\alpha_{0}:$ a constant;

$\alpha_{1}, \ldots, \alpha_{6}:$ the short-term coefficients; 
$\lambda_{1}, \ldots, \lambda_{6}$ : the long-term coefficients;

$\mu_{\mathrm{t}} \sim \operatorname{iid}(0 ; \sigma)$ : the error term (white noise).

However, the expectations regarding the effects of the explanatory variables on the dependent variable are shown in Table 1. A plus sign $(+)$ indicates a positive effect and a minus sign (-) shows a negative effect of the dependent variable on GDP.

Table 1

\section{Used variables}

\begin{tabular}{|l|l|c|}
\hline \multicolumn{1}{|c|}{ Variables } & \multicolumn{1}{c|}{ Description } & Expected effects \\
\hline GDP & Gross Domestic Product & \\
\hline HEV & Natural Rubber Export & + \\
\hline PAL & Palm oil exports & + \\
\hline INV & Agricultural investment & + \\
\hline LAB & Labor force & + \\
\hline TRA & Trade opening & + \\
\hline
\end{tabular}

Source: author's research on the basis of the theory.

Results and discussion. Descriptive characteristics. In terms of standard deviation (Table 2), the variable «LNHEV» is more volatile than all other variables. In fact, natural rubber appears to be more sensitive to the effects of price fluctuations on world markets, unlike the other variables.

Table 2

Descriptive analysis of variables

\begin{tabular}{|l|c|c|c|c|c|c|}
\hline \multicolumn{1}{|c|}{ Indicators } & LNGDP & LNPAL & LNHEV & LNINV & LNLAB & LNTRA \\
\hline Mean & 23.35179 & 18.00000 & 18.57972 & 21.27969 & 16.52384 & 21.97824 \\
\hline Median & 23.18475 & 17.94426 & 18.14920 & 21.22226 & 16.58086 & 21.91284 \\
\hline Maximum & 24.31714 & 19.42163 & 20.84696 & 22.74316 & 16.98081 & 22.75346 \\
\hline Minimum & 22.64579 & 16.98771 & 16.88138 & 20.39769 & 15.93100 & 21.12628 \\
\hline Std. Dev. & 0.492076 & 0.634972 & 1.150894 & 0.642336 & 0.304973 & 0.435864 \\
\hline Skewness & 0.537840 & 0.659003 & 0.463906 & 0.867642 & -0.353594 & 0.150999 \\
\hline Kurtosis & 2.149303 & 2.680079 & 1.966746 & 3.004574 & 1.980881 & 2.343337 \\
\hline Jarque-Bera & 2.899525 & 2.835882 & 2.973027 & 4.642314 & 2.372190 & 0.805380 \\
\hline Probability & 0.234626 & 0.242212 & 0.226160 & 0.098160 & 0.305412 & 0.668519 \\
\hline Sum & 864.0162 & 665.9999 & 687.4497 & 787.3484 & 611.3821 & 813.1950 \\
\hline Sum Sq. Dev. & 8.717008 & 14.51482 & 47.68402 & 14.85343 & 3.348313 & 6.839172 \\
\hline Observations & 37 & 37 & 37 & 37 & 37 & 37 \\
\hline
\end{tabular}

Source: author's estimation using Eviews 10.

Gross Domestic Product (GDP) of Ivory Coast (USD). The evolution of GDP in Ivory Coast is undergoing three (3) major phases according to Fig. 1. The period from 1980 to 1985 is marked by a slowdown in economic growth due to the deterioration in the terms of trade linked to the economic crisis of the 1980s. Then, the period from 1985 to 2004 shows a slight improvement in the economic situation due to the measures of the structural adjustment programme adopted by the State. Finally, the period from 2005 to 2016 is characterised by continuous and sustained GDP growth.

Natural rubber exports to Ivory Coast in current USD. There are two (2) main trends in natural rubber exports according to Fig. 2. Firstly, from 1980 to 2011, there 


\section{Agricultural and Resource Economics: International Scientific E-Journal http://are-journal.com}

was a gradual evolution of exports due to the agricultural diversification policy undertaken by the State of Ivory Coast after the crisis in the cocoa-coffee sector.

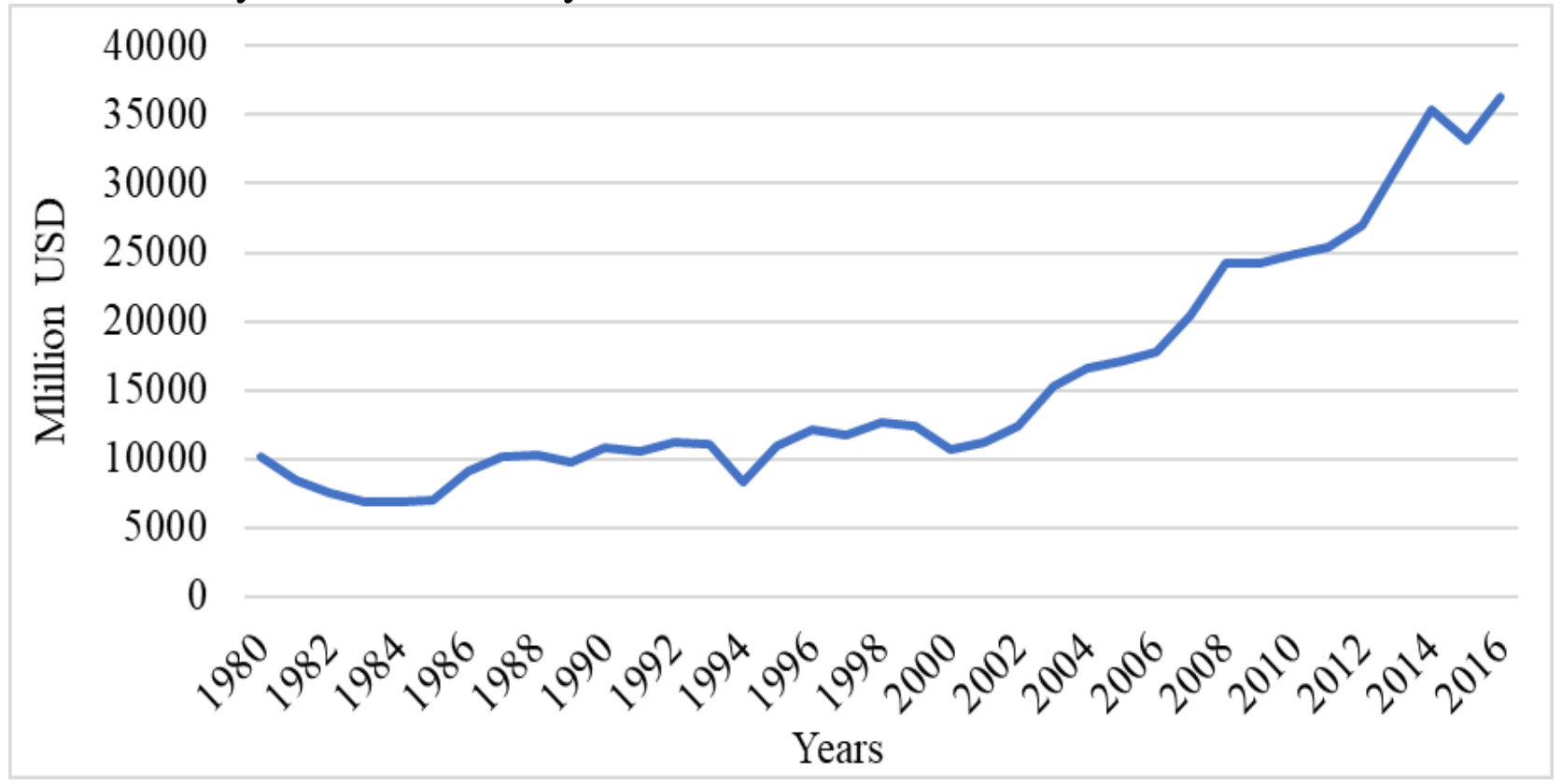

Fig. 1. Evolution of GDP from 1980 to 2016

Source: author's research on World Bank data.

Then, from 2011 to 2016, there was a drastic decline in the value of exports from over one billion to less than sixty million USD due to the fall in prices on the international market.

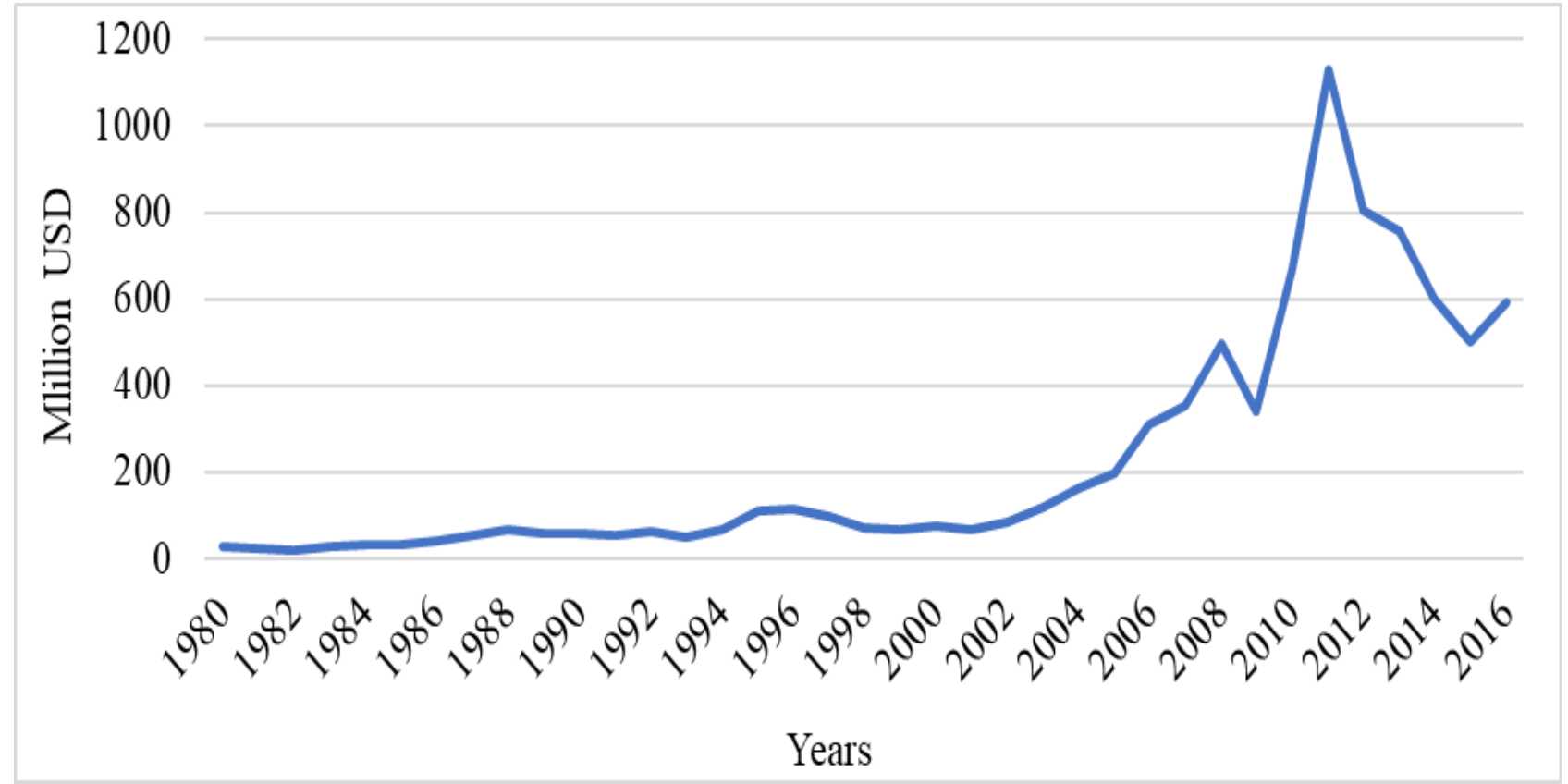

Fig. 2. Natural Rubber Export Trends from 1980 to 2016

Source: author's research based on World Bank data.

Palm oil exports. According to Fig. 3, the evolution of palm oil export shows five (5) periods. Indeed, the years 1980-1983 were marked by a fall in the level of exports due to the effects of the world economic crisis which caused deterioration in the prices of raw materials on the international market. In addition, from 1983 to 
1999, a clear improvement in the value of palm oil exports was observed. However, from 1999 to 2002, a new phase of regression in exports due to the military-topolitical crisis was noted. Moreover, the period 2002-2012 presented a phase of expansion of palm oil exports due to the incentives introduced by Ivory Coast. Finally, from 2012 to 2016, a drastic drop in the value of exports due to the fall in world prices was noted again.

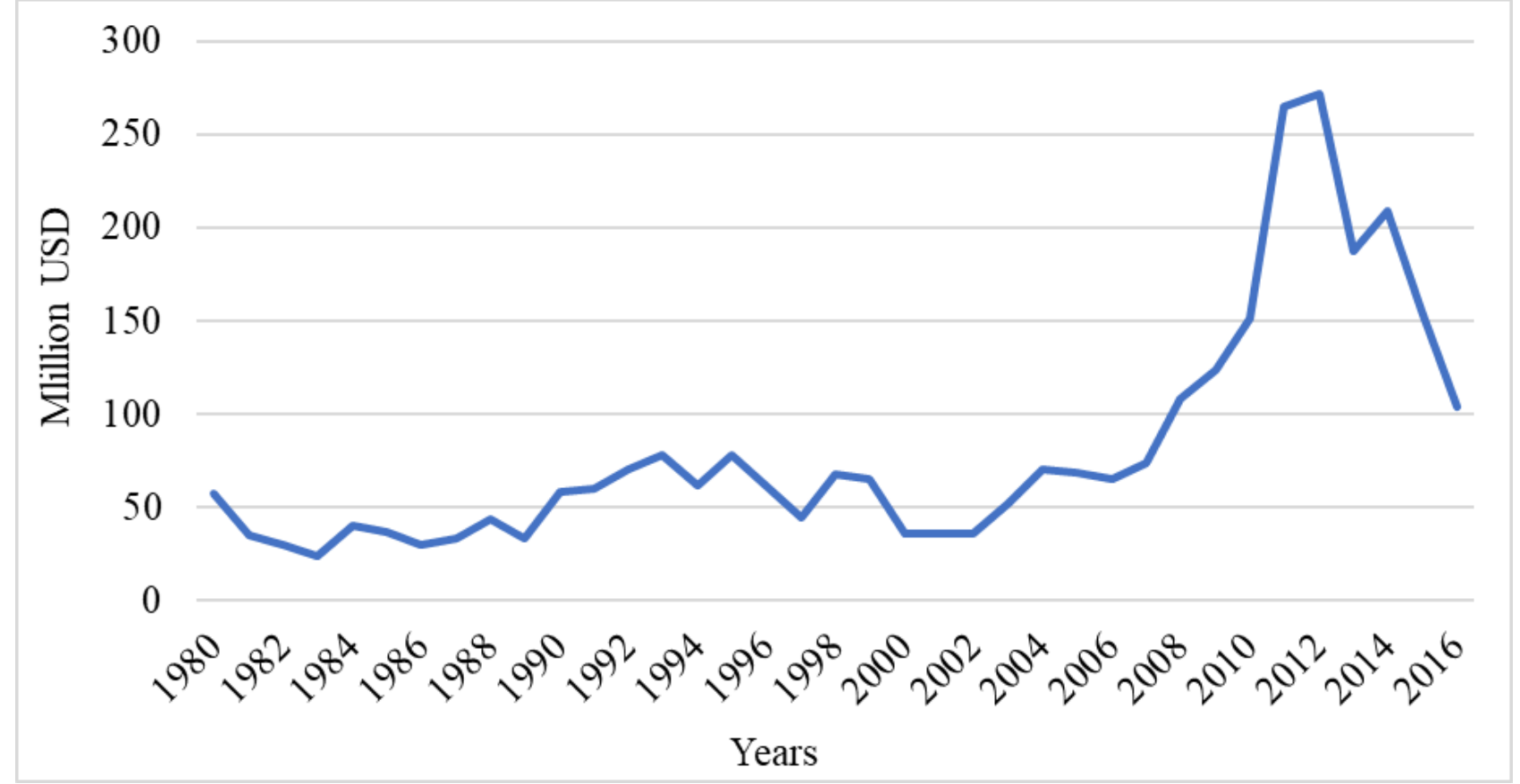

Fig. 3. Evolution of Palm exports from 1980 to 2016

Source: author's research based on World Bank data.

Level stationarity tests. The Augmented Dickey-Fuller (ADF) and PhillipsPerron (PP) tests show non-stationary series. They indicate the presence of unit root levels, hence the need to differentiate between them (Table 3).

Table 3

Level stationarity tests

\begin{tabular}{|l|l|c|c|c|}
\hline \multicolumn{1}{|c|}{ Indicators } & \multicolumn{1}{|c|}{ Methods } & t-Statistic & Probability & Stationnarity \\
\hline \multirow{2}{*}{ LnGDP } & ADF & 0.578796 & 0.9871 & NO \\
\cline { 2 - 5 } & Phillips-Perron & 0.829972 & 0.9932 & NO \\
\hline \multirow{2}{*}{ LnHEV } & ADF & -1.271266 & 0.6322 & NO \\
\cline { 2 - 5 } & Phillips-Perron & -0.947428 & 0.7611 & NO \\
\hline \multirow{2}{*}{ LnPAL } & ADF & -1.309744 & 0.6144 & NO \\
\cline { 2 - 5 } & Phillips-Perron & -1.384171 & 0.5791 & NO \\
\hline \multirow{2}{*}{ LnLAB } & ADF & -1.695999 & 0.0847 & NO \\
\cline { 2 - 5 } & Phillips-Perron & -1.671719 & 0.0889 & NO \\
\hline \multirow{2}{*}{ LnTRA } & ADF & -0.354963 & 0.9064 & NO \\
\cline { 2 - 5 } & Phillips-Perron & -0.458956 & 0.8878 & NO \\
\hline \multirow{2}{*}{ LnINV } & ADF & -1.012251 & 0.7385 & NO \\
\cline { 2 - 5 } & Phillips-Perron & -0.795064 & 0.8085 & \\
\hline
\end{tabular}

Source: author's estimation using Eviews 10.

First difference stationarity tests. All variables are integrated as first differences (Table 4). 
First difference stationarity tests

\begin{tabular}{|l|l|c|c|c|}
\hline \multicolumn{1}{|c|}{ Indicators } & \multicolumn{1}{|c|}{ Methods } & t-Statistic & Probability & Stationnarity \\
\hline \multirow{2}{*}{ LnGDP } & ADF & -5.640983 & 0.0000 & YES \\
\cline { 2 - 5 } & Phillips-Perron & -5.946187 & 0.0000 & YES \\
\hline \multirow{2}{*}{ LnHEV } & ADF & -7.285721 & 0.0000 & YES \\
\cline { 2 - 5 } & Phillips-Perron & -17.93232 & 0.0001 & YES \\
\hline \multirow{2}{*}{ LnPAL } & ADF & -5.913999 & 0.0000 & YES \\
\cline { 2 - 5 } & Phillips-Perron & -5.945207 & 0.0001 & YES \\
\hline \multirow{2}{*}{ LnLAB } & ADF & -2.471161 & 0.0150 & YES \\
\cline { 2 - 5 } & Phillips-Perron & -2.452355 & 0.0157 & YES \\
\hline \multirow{2}{*}{ LnINV } & ADF & -5.159799 & 0.0002 & YES \\
\cline { 2 - 5 } & Phillips-Perron & -5.195943 & 0.0001 & YES \\
\cline { 2 - 5 } & ADF & -7.418006 & 0.0000 & YES \\
\cline { 2 - 5 } & Phillips-Perron & -0.947428 & 0.0000 & YES \\
\hline
\end{tabular}

Source: author's estimation using Eviews 10.

Optimal delay. According to Fig. 4, of the five (5) criteria, three (FPE, AIC, HQ) indicate that the optimal delay is 3 . The other two (2) show that the optimal delay is 2 . Then, the number of delays selected is 3 .

Akaike Information Criteria (top 20 models)

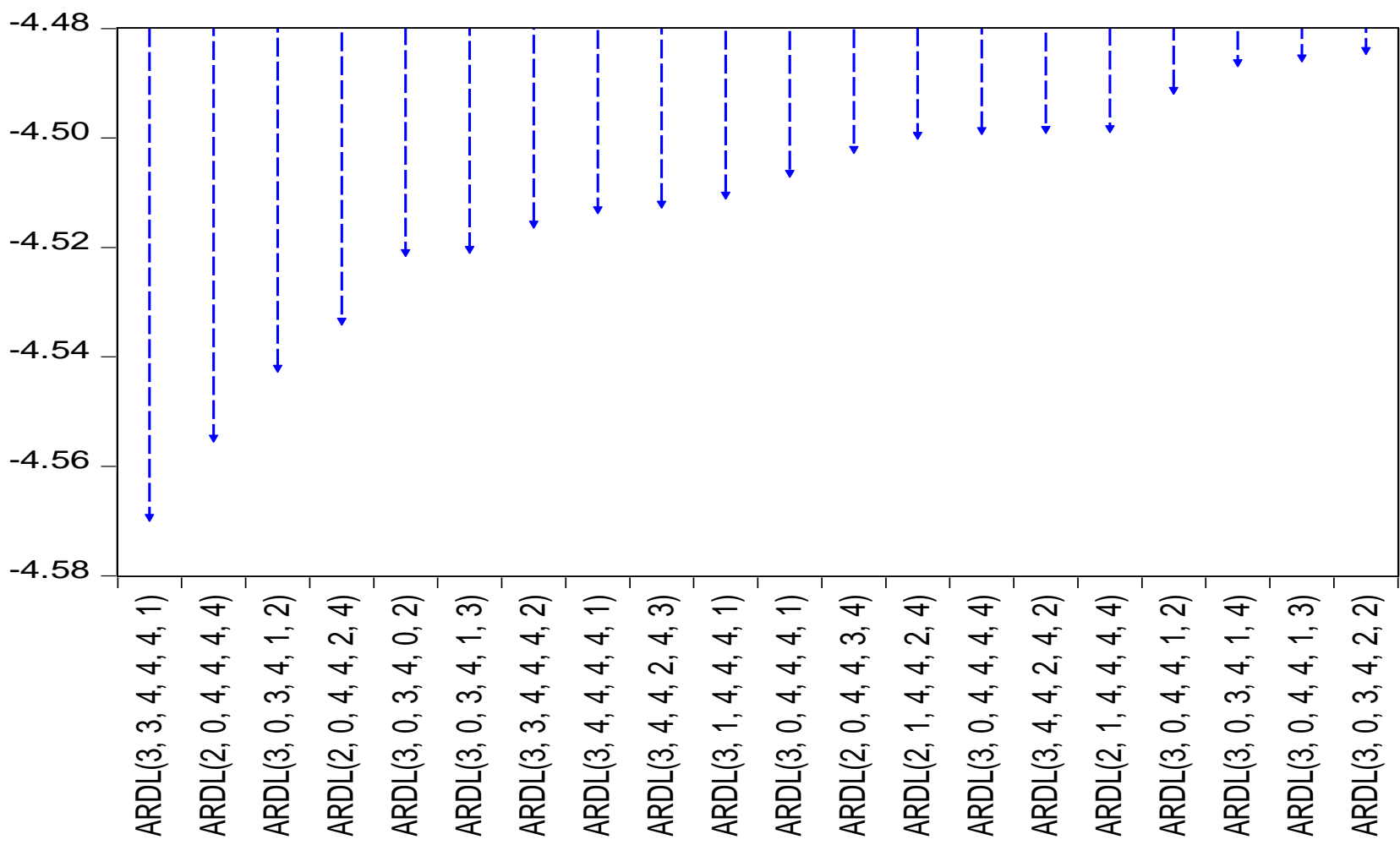

Source: author's estimation using Eviews 10.

\section{Fig. 4. AKAIKE Information Criteria}

Diagnostic tests of the ARDL model $(3,4,4,1)$. The null hypothesis is rejected for each model validation test because their probability is more than $5 \%$. Thus, there is an absence of autocorrelation of errors, an absence of heteroscedasticity of errors and a normality of errors (Table 5). 
ARDL Model Diagnostic Test Results $(3,4,4,1)$

\begin{tabular}{|l|c|c|c|c|}
\hline \multicolumn{1}{|c|}{ Tests } & Hypothesis & F-Statistic & Probabilities & Decision \\
\hline Breusch-Godfrey & Autocorrelation & 4.87 & 0.11 & No autocorrelation of errors \\
\hline Harvey & Heteroscedasticity & 1.15 & 0.46 & No error heteroscedasticity \\
\hline ARCH & Heteroscedasticity & 1.42 & 0.25 & No error heteroscedasticity \\
\hline Jarque-Bera & Normality & 3.55 & 0.17 & Error normality \\
\hline Ramsey (Fischer Stat) & Specification & 3.31 & 0.16 & Good specification \\
\hline
\end{tabular}

Source: author's estimation using Eviews 10.

CUSUM and CUSUM squared stability tests. The stability tests of CUSUM and CUSUM squared also reveal that the model is perfectly stable. The model is thus well specified, stable and validated. In addition, these figures indicate that there is an autocorrelation between the different variables (Fig. 5 and 6).

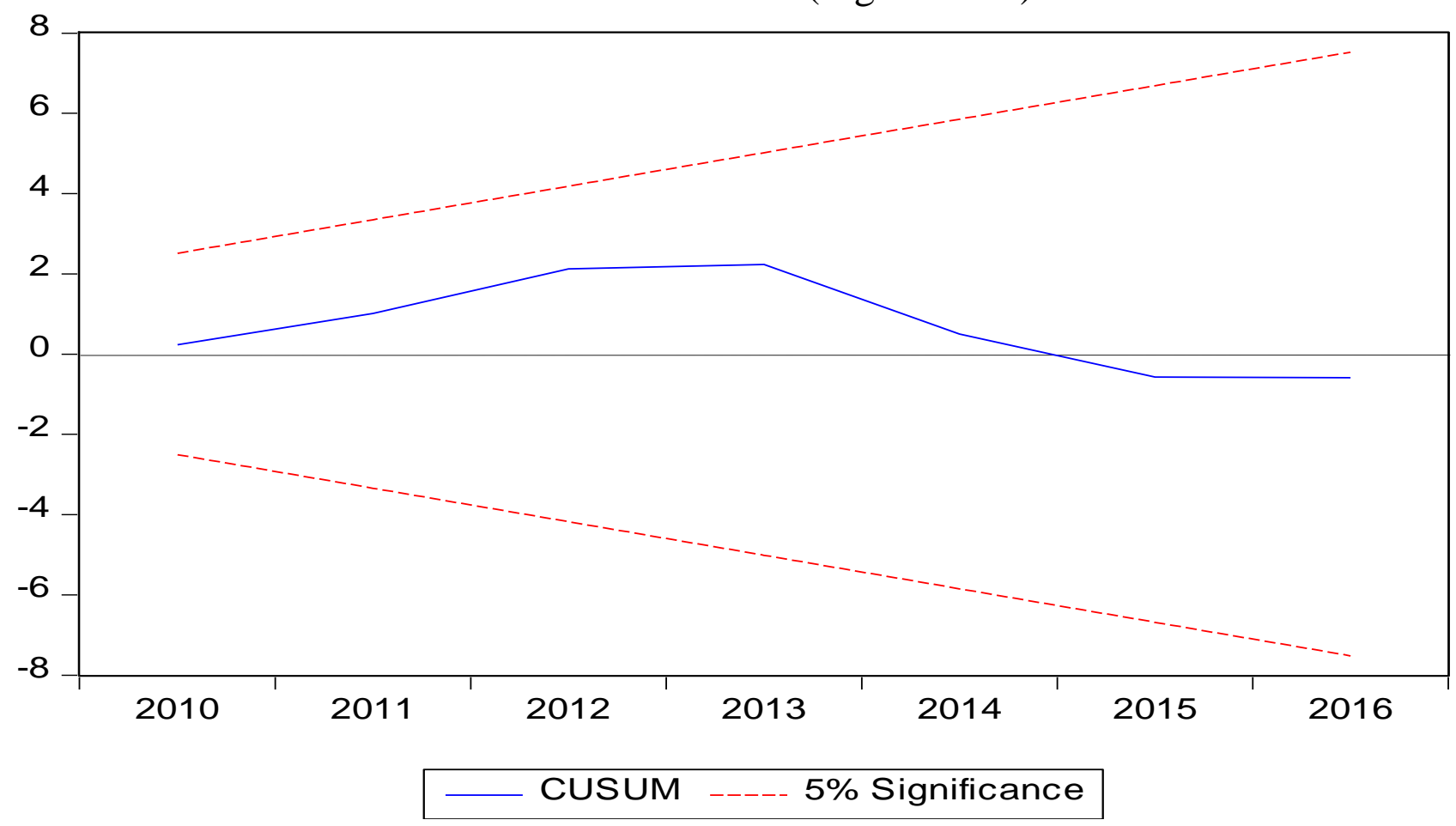

Fig. 5. CUSUM stability test

Source: author's estimation using Eviews 10.

Terminal Cointegration Test. Table 6 confirms that there is a cointegration relationship between the variables in the series due to the fact that the value of the Fisher statistic (9.44) is above the upper bound at all thresholds $(10 \% ; 5 \% ; 2.5 \%$ and $1 \%)$. It is therefore possible to estimate the long-term effects of the explanatory variables (ln $\mathrm{HEV}$, ln PAL, ln LAB, In TRA, ln INV) on the dependent variable (LnGDP).

ARDL model estimation. According to Table 7, the coefficients of determination (R2) and adjusted determination (A-R2) have values of 0.999438 and 0.997432 respectively. This means that the variation of the gross domestic product is taken into account by the explanatory variables of the model at $99.94 \%$. Moreover, the variation of the gross domestic product is explained by the explanatory variables retained at $99.74 \%$. 
Agricultural and Resource Economics: International Scientific E-Journal http://are-journal.com

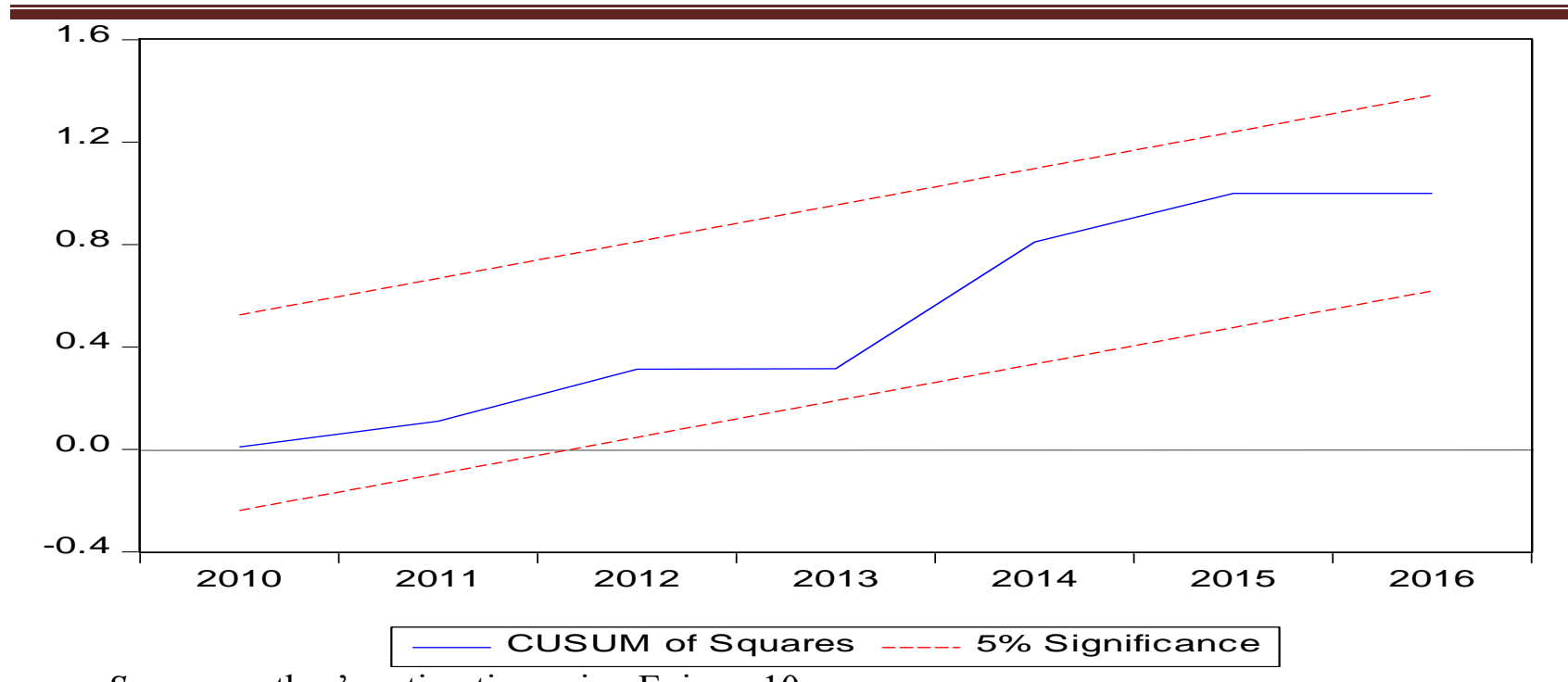

Source: author's estimation using Eviews 10.

Table 6

Result of the cointegration test of Pesaran et al (2001)

\begin{tabular}{|l|c|c|}
\hline \multicolumn{1}{|c|}{ Statistics Test } & Value & $\mathrm{K}$ \\
\hline F-Statistic & 9.44 & 5.00 \\
\hline Critical values of terminals & \multicolumn{2}{|c|}{} \\
\hline Thresholds & Lower terminals I (0) & Upper terminals I (1) \\
\hline $10 \%$ & 2.75 & 3.79 \\
\hline $5 \%$ & 3.12 & 4.25 \\
\hline $2.5 \%$ & 3.49 & 4.67 \\
\hline $1 \%$ & 3.93 & 5.23 \\
\hline
\end{tabular}

Source: author's estimation using Eviews 10.

Table 7

\section{ARDL model estimation}

Dependent Variable: LNGDP

Dynamic regressors (4 lags, automatic): LNHEV LNPAL LNLAB LNTRA

Selected Model: ARDL(3, 3, 4, 4, 4, 1)

Variable

LNGDP(-1)

LNGDP(-2)

LNHEV

Coefficient

Std. Error

t-Statistic

Prob.*

LNPAL

0.169422

0.225469

0.106896

0.003404

0.067313

1.584915

0.1570

LNLAB

0.069497

0.017490

3.349564

0.0123

LNTRA

0.181067

0.016148

0.194605

0.8512

\section{LNINV}

R-squared

Adjusted R-squared

0.405936

0.046676

4.303690

3.879238

0.034063

0.198013

0.011449

11.91736

0.999438

17.29524

Mean dependent var

0.997432

S.D. dependent var

S.E. of regression

Sum squared resid

0.024327

Akaike info criterion

0.004143

Log likelihood

F-statistic

101.3937

498.2488

0.000000

Schwarz criterion

0.8512

0.0061
0.0000

Prob(F-statistic)

Durbin-Watson stat

0.0000

*Note: p-values and any subsequent tests do not account for model selection. Source: author's estimation using Eviews 10. 


\section{Agricultural and Resource Economics: International Scientific E-Journal http://are-journal.com}

Tests for correlation and causality between variables. The simple correlation matrix between the variables shows no relationship between the dependent variable (GDP) and the explanatory variables in the first column, as the degree of association is less than 0.50 . The correlation matrix is based on a simple correlation between variables, and the dependent variable (GDP) and the explanatory variables in the second column are not related (Table 8).

Table 8

Simple correlation matrix between variables

\begin{tabular}{|l|c|c|c|c|c|c|}
\hline Indicators & LNGDP & LNHEV & LNPAL & LNLAB & LNTRA & LNINV \\
\hline LNGDP & 1 & 0.95148 & 0.86392 & 0.77003 & 0.96261 & 0.80149 \\
\hline LNHEV & 0.95148 & 1 & 0.87759 & 0.78785 & 0.91045 & 0.68669 \\
\hline LNPAL & 0.86392 & 0.87759 & 1 & 0.54694 & 0.84635 & 0.64489 \\
\hline LNLAB & 0.77003 & 0.78785 & 0.54694 & 1 & 0.71606 & 0.47732 \\
\hline LNTRA & 0.96261 & 0.91045 & 0.84635 & 0.71606 & 1 & 0.67543 \\
\hline LNINV & 0.80149 & 0.68669 & 0.64489 & 0.47732 & 0.67543 & 1 \\
\hline
\end{tabular}

Source: author's estimation using Eviews 10.

Estimation of Short-term coefficients. The results reported in Table 9 indicate that labour (LAB) has a positive and significant effect on Gross Domestic Product (GDP) in the short term. Indeed, a $1 \%$ increase in labour force stimulates the growth of the domestic product by $18.10 \%$. When it is delayed by one period, it always has a positive and significant effect on economic growth. Similar results were reported by Theodore et al. (2019), showing that labour force had significant positive effects on economic growth. According to this author, the labour has a multiplying power.

Moreover, agricultural investment (INV) has a positive and significant influence on short-term economic development. A $1 \%$ change in agricultural investment leads to a $19.80 \%$ increase in GDP. In addition, when it is delayed by one or two periods, it has the same positive and significant effect on GDP. The study by Khan and Kumar (1997) confirmed this result. According to these authors, public and private investment always has a significant impact on economic growth.

On the other hand, exports of natural rubber provide a positive but not significant boost to GDP in the short term. Thus, when the monetary value of natural rubber exports varies by $1 \%$, GDP grows by $0.34 \%$. However, when lagged one or two periods, natural rubber exports exert a positive and significant influence on economic growth of $4.10 \%$ and $6.38 \%$ respectively. These results show that rubber tree cultivation does not have an immediate effect in the short term. This cash crop is beneficial in the long term.

In addition, palm oil exports stimulate GDP positively and significantly in the short term. Therefore, when the monetary value of palm oil exports increases by $1 \%$, GDP grows by $6.94 \%$. Moreover, when palm oil exports are delayed by one and two periods, the $1 \%$ increase in palm oil exports causes a $20.23 \%$ and $19.22 \%$ growth in Gross Domestic Product, respectively. These results show that palm oil exports have a favourable impact on economic growth in the short term. This is in agreement with Fakhre and Godwin (2016), who found out that GDP and palm oil exports have a short and long-run equilibrium relationship. 
Finally, the opening up of trade has a positive and significant influence on GDP in the short term. When its monetary value increases by $1 \%$, GDP grows by $40.59 \%$. Conversely, when it is delayed by one and two periods, its $1 \%$ increase leads to a decrease in economic growth of $2.20 \%$ and $0.46 \%$ respectively. These results show that trade openness undeniably contributes to economic growth.

Table 9

Short-term coefficients

\begin{tabular}{|l|c|c|c|c|}
\hline \multicolumn{1}{|c|}{ Indicators } & \multicolumn{4}{|c|}{ Conditional Error Correction Regression } \\
\hline \multicolumn{1}{|c|}{ Variable } & Coefficient & Std. Error & T-Statistic & Prob. \\
\hline T & 12.32243 & 2.666462 & 4.621266 & 0.0024 \\
\hline LREND & 0.030963 & 0.009018 & 3.433635 & 0.0109 \\
\hline LNHEV(-1) & 1.213571 & 0.200422 & 6.055077 & 0.0005 \\
\hline LNPAL(-1) & 0.081061 & 0.075169 & 1.078383 & 0.3166 \\
\hline LNLAB(-1) & 0.272113 & 0.093670 & 2.905035 & 0.0228 \\
\hline LNTRA(-1) & 0.102527 & 0.076925 & 1.332818 & 0.2243 \\
\hline LNINV(-1) & 0.580766 & 0.088983 & 6.526680 & 0.0003 \\
\hline D(LNGDP(-1)) & 0.283822 & 0.051731 & 5.486515 & 0.0009 \\
\hline D(LNGDP(-2)) & 0.044150 & 0.116184 & 0.379996 & 0.7152 \\
\hline D(LNHEV) & 0.181320 & 0.112813 & 1.607253 & 0.1520 \\
\hline D(LNHEV(-1)) & 0.003404 & 0.037975 & 0.089629 & 0.9311 \\
\hline D(LNHEV(-2)) & 0.041084 & 0.050115 & 0.819804 & 0.4393 \\
\hline D(LNPAL) & 0.063829 & 0.054383 & 1.173680 & 0.2789 \\
\hline D(LNPAL(-1)) & 0.069497 & 0.035061 & 1.982134 & 0.0879 \\
\hline D(LNPAL(-2)) & 0.192215 & 0.057669 & 3.333068 & 0.0419 \\
\hline D(LNPAL(-3)) & 0.053152 & 0.044022 & 1.207412 & 0.2665 \\
\hline D(LNLAB) & 0.181067 & 0.101345 & 1.786646 & 0.1172 \\
\hline D(LNLAB(-1)) & 0.150233 & 0.087711 & 1.712824 & 0.1305 \\
\hline D(LNLAB(-2)) & 0.047774 & 0.109458 & 0.436457 & 0.6757 \\
\hline D(LNLAB(-3)) & 0.173170 & 0.107575 & 1.609760 & 0.1515 \\
\hline D(LNTRA) & 0.405936 & 0.073958 & 5.488735 & 0.0009 \\
\hline D(LNTRA(-1)) & 0.022057 & 0.091268 & 0.241671 & 0.8160 \\
\hline D(LNTRA(-2)) & -0.004620 & 0.102082 & -0.045257 & 0.9652 \\
\hline D(LNTRA(-3)) & -0.126556 & 0.068758 & -1.840603 & 0.1082 \\
\hline D(LNINV) & 0.198013 & 0.024858 & 7.965601 & 0.0001 \\
\hline
\end{tabular}

Note. *P-Value Incompatible With T-Bounds Distribution.

Source: author's estimation using Eviews 10.

Estimation of Long-term coefficients. The results of the long-term coefficients (Table 10) show that labour force (LAB) has a positive and significant effect on Gross Domestic Product (GDP). Indeed, when the population varies by $1 \%$, the Gross Domestic Product grows by $8.44 \%$. However, it can be seen that the labour multiplier effect declines in the long term. It means that in the long term, the labour force could have a negative impact on economic growth. Sandron (2002) confirmed these results. He started from the argument that the multiplier power of the labour force is infinitely greater than the power of the land to produce human subsistence.

Furthermore, agricultural investment (INV) has a positive and significant 
influence on gross domestic product (GDP) in the long term. A $1 \%$ increase in capital causes an increase in economic growth of $23.39 \%$. These results show that investment boosts long-term economic growth. The work carried out by Kouakou (2020) supported these assertions.

Also, natural rubber exports have a positive and significant effect on the gross domestic product in the long term. Indeed, when the monetary value of natural rubber exports increases by $1 \%$, GDP grows by $6.68 \%$. These results are consistent with those of N'Zué (2003), who in a study on Ivory Coast, analysed the Granger causal relationship between export expansion and economic growth and determined its implications for wealth creation.

Moreover, palm oil exports have a positive and significant impact on long-term economic growth. For example, when the monetary value of palm oil exports varies by $1 \%$, GDP increases by $22.42 \%$. These results are in line with those of Greenaway, Morgan and Wright (1999) who also showed that export growth drives economic growth. Similar results found by Sertoglu and al. (2017).

Finally, trade openness causes a positive and significant influence on long-term economic development. Therefore, when its monetary value increases by $1 \%$, GDP grows by $47.85 \%$. These results show that trade openness inevitably influences economic growth.

Table 10

Long-term coefficients

\begin{tabular}{|l|l|l|l|l|}
\hline \multicolumn{5}{|l|}{ Levels Equation } \\
\hline Case 5: Unrestricted Constant And Unrestricted Trend \\
\hline Variable & Coefficient & Std. Error & T-Statistic & Prob. \\
\hline LNHEV & 0.066796 & 0.026445 & 2.525836 & 0.0395 \\
\hline LNPAL & 0.224225 & 0.037685 & -5.949988 & 0.0006 \\
\hline LNLAB & 0.084484 & 0.031360 & 2.693985 & 0.0309 \\
\hline LNTRA & 0.478559 & 0.022320 & 21.44128 & 0.0000 \\
\hline LNINV & 0.233874 & 0.018222 & 12.83454 & 0.0000 \\
\hline $\begin{array}{l}\text { EC = LNGDP - 0.0668*LNHEV + 0.2242*LNPAL+ 0.0845*LNLAB + } \\
0.2339 * \text { INV }\end{array}$
\end{tabular}

Source: author's estimation using Eviews 10.

Conclusions. In view of the results, it can be concluded that palm oil exports have a positive and significant effect on economic growth in the short and long term.

However, natural rubber exports have a positive, but not significant, influence on the gross domestic product in the short term. On the other hand, in the long term, they positively and significantly boost GDP. On the other hand, the labor force has a positive and significant influence on economic development in the short and long term. However, in the absence of better planning, it could have a negative impact on economic growth in the long term.

Agricultural investment, on the other hand, causes a positive and significant relationship on the gross domestic product in the short and long term. Finally, trade openness also promotes economic development in the short and long term.

From all of the above, it is clear that the natural rubber and the palm oil sectors 
remain undeniably the mainstay of the Ivorian economy. Therefore, we recommend increasing the productivity of planters, through the modification of technical itineraries and the use of improved plant material; the training and sensitization of producers and their families to the problem of deforestation, particularly with regard to climate change, the distribution of improved seedlings, and finally, the financing of farms.

\section{References}

1. Agbonkpolor, N. B., Alufohai, G. O., Mesike, C. S. and Adindu, A. G. (2017), Co-integration and causality analysis in major natural rubber markets of Nigeria. Trends in Agricultural Economics, vol. 10, no. 2, pp. 12-17. https://doi.org/10.3923/tae.2017.12.17.

2. Boztosun, D., Aksoylu, S., Ulucak, Z. S. (2016), The role of human capital in economic growth. Economics World, vol. 4, no. 3, pp. 101-110. https://doi.org/10.17265/2328-7144/2016.03.001.

3. Banque Mondiale (2016), Performances économiques ivoiriennes depuis la fin de la crise post-électorale. Report, available at: http://documents.banquemondiale.org/curated/fr/132981468230123662/pdf.

4. Faycal, M., and Ali, H. M. (2016), Economic growth and government subventions for agriculture sector in Algeria: an ARDL model. Arab Economic and Business Journal, vol. 11, is. 2, pp. 105-114. https://doi.org/10.1016/j.aebj.2016.10.001.

5. Fakhre, A. and Godwin, M. (2016), Causality between agricultural exports and GDP and its implications for Tanzanian economy. Journal of Economics and Finance, vol. 8, is. 6, pp. 36-49. https://doi.org/10.9790/5933-0806013649.

6. Greenaway, D., Morgan, W. and et Wright, P. (1999), Exports, export composition and growth. The Journal of International Trade \& Economic Development, vol. 8, is. 1, pp. 41-51. https://doi.org/10.1080/09638199900000004.

7. Henneberry, D. M. and Curry, K. (1995), Agricultural import demand in large markets: an aggregate analysis with high and low growth subgroups. Journal of Food Products Marketing, vol. 2, is. 3, pp. 67-87. https://doi.org/10.1300/J038v02n03_05.

8. INS (2014), Recensement Général de la population et de l'habitat en Côte d'Ivoire. Report, available

at: http://www.ins.ci/n/documents/RGPH2014_expo_dg.pdf.

9. Sertoglu, K., Ugural, S. and Bekun, F. V. (2017), The contribution of agricultural sector on economic growth of Nigeria. International Journal of Economics and Financial Issues, vol. 7, no. 1, pp. 547-552.

10. Keho, Y. (2017), The exports and economic growth nexus in Cote d'Ivoire: evidence from a multivariate time series analysis. Asian Journal of Economic Modelling, vol. 5, no. 2, 2 pp. 135-146. https://doi.org/10.18488/journal.8/2017.5.2/8.2.135.146.

11. Khan, M. and Kumar, M. (1997), Public and Private Investment and the Growth Process in Developing Countries. Oxford Bulletin of Economics and Statistics, vol. 59, is. 1, pp. 69-88. https://doi.org/10.1111/1468-0084.00050. 
12. Khan, W. and Ansari, S. A. (2018), Does agriculture matter for economic growth of Uttar Pradesh (India)? Economy of Region, vol. 14, no. 3, pp. 1029-1037. https://doi.org/10.17059/2018-3-24.

13. Kouakou, K. P. A. (2020), Effect of agricultural and non-agricultural exports on economic growth in Ivory Coast. Review of Agricultural and Applied Economics, vol. 23, no. 2, pp. 45-53. https://doi.org/10.15414/raae.2020.23.02.45-53.

14. Kpemoua, P. (2016), Exportations et croissance économique au Togo, available at: https://halshs.archives-ouvertes.fr/halshs-01332738/document.

15. Lee, K. W. and Masih, M. (2018), Investigating the causal relationship between exchange rate variability and palm oil export: evidence from Malaysia based on ARDL and nonlinear ARDL approaches, available at: https://mpra.ub.unimuenchen.de/91801/.

16. Maxime, C. (2020), La filière palmier à huile en Côte d'Ivoire: un condensé des enjeux $\mathrm{du}$ développement durable. Report, available at: http://www.fondationfarm.org/zoe.php?s=blogfarm\&w=wt\&idt=3835.

17. N'zué, F. F. (2003), Le rôle des exportations dans le processus de croissance economique de la Côte d'Ivoire: ses implications pour des stratégies de créations d'emplois durables. African Development Review, vol. 15, is. 2-3, pp. 199-217. https://doi.org/10.1111/j.1467-8268.2003.00071.x.

18. Rakhmetullina, S., Isiksal, A. Z. and Chimezi, J. O. (2017), Economic growth, agriculture and industrialization in Nigeria: an ARDL bound testing approach. International Journal of Economic Perspectives, vol. 11, no. 2, pp. 45-54.

19. Rodrigue, T. (1987), Le rôle des exportations dans la croissance économique des régions et des pays. Canadian Journal of Regional Science, vol. 10, is. 3, pp. 341-349.

20. Sakketa, T. and Gerber, N. (2017), Rural shadow wages and youth agricultural labor supply in Ethiopia: evidence from farm panel data. ZEF-Discussion Papers on Development Policy, no. 236. https://doi.org/10.2139/ssrn.2956283.

21. Sandron, F. (2002), Croissance économique et croissance démographique: théories, situations, politiques in Le monde en développement: démographie et enjeux socio-économiques, ed. Charbit Y. La Documentation Française, Paris, France, available at: https://horizon.documentation.ird.fr/exl-doc/pleins_textes/divers1709/010029446.pdf.

22. Siaw, A., Jiang, Y. S., Pickson, R. B. and Dunya, R. (2018), Agricultural exports and economic growth: a disaggregated analysis for Ghana. Theoretical Economics Letters, vol. 8, no. 11, pp. 2251-2270. https://doi.org/10.4236/tel.2018.811147.

23. Tamaschke, H. V. (1979), Exports and economic growth: applications of the staple theory, J. K. Publishers, London, UK.

24. Theodore, M., Qiang, L., Eric, N. and Ekanayake, E. M. B. P. (2019), Do coffee exports have impact on long-term economic growth of countries? Agricultural Economics - Czech, vol. 65, no. 8, pp. 385-393. https://doi.org/10.17221/283/2018AGRICECON. 
25. Tyler, W. G. (1981), Growth and export expansion in developing countries: some empirical evidence. Journal of Development Economics, vol. 9, pp. 121-130.

26. Twumasi, M. A., Jiang, Y. and Acheampong, M. O. (2019), Capital and credit constraints in the engagement of youth in Ghanaian agriculture. Agricultural Finance Review, vol. 80, no. 1, pp. 22-37. https://doi.org/10.1108/afr-11-2018-0100.

27. Zahonogo, P. (2016), Trade and economic growth in developing countries: evidence from Sub-Saharan Africa. Journal of African Trade, vol. 3, no. 1, pp. 4156. https://doi.org/10.1016/j.joat.2017.02.001.

28. Zamble, C. (2015), Impact du changement de politique agricole dans la filière cacao en Côte d'Ivoire: analyse de son évolution, available at: https://corpus.ulaval.ca/jspui/bitstream/20.500.11794/26039/1/31683.pdf.

How to cite this article? Як цитувати цю статтю?

Стиль-ДСТУ:

Kouakou P.-A. K. Role of trade in natural rubber and palm oil in the composition of GDP in Ivory Coast. Agricultural and Resource Economics. 2020. Vol. 6. No. 3. Pp. 48-63. URL: http://are-journal.com.

Style-Harvard:

Kouakou, P.-A. K. (2020), Role of trade in natural rubber and palm oil in the composition of GDP in Ivory Coast. Agricultural and Resource Economics, vol. 6, no. 3, pp. 48-63, available at: http://are-journal.com. 